\title{
Biochemical Profiling and Evaluation of Antioxidant and Cytotoxic Effect of Different Extracts of Strychnos potatorum
}

\author{
K. M. Thara* \\ Department of Biotechnology, University of Calicut, CVU Campus, Thanjippalam \\ Kerala, India \\ *Corresponding author
}

A B S T R A C T

\begin{tabular}{|l|}
\hline Key w or d s \\
Strychnos \\
potatorum, \\
Antioxidant \\
activity, Flavanoids, \\
Quercetin, HPLC \\
\hline Article Info \\
\hline $\begin{array}{l}\text { Accepted: } \\
\text { 08 January } 2020 \\
\text { Available Online: } \\
\text { 10 February } 2020\end{array}$ \\
\hline
\end{tabular}

\section{Introduction}

The seeds of the plant Strychnos potatorum are widely used in the treatment of different ailments like bronchitis, diarroea, dysentery, urinary tract infections (Kavitha et al., 2014). Curative properties of a plant product are due to the presence of secondary metabltes lke flavanoids, alkaloids, terpenods either alone or as synergistic action. Flavonoids are very important in preventing different diseases like cancer, inflammation, diabetes etc. as it is a strong antioxidant agent (Almedia et al., 2008).Evidences suggest that cellular damage or oxidative injury arising from production of free radicals or reactive oxygen species (ROS) are critical causative factors in the pathogenesis of many neurodegenerative disorders, inflammatory conditions, autoimmune diseases, atherosclerosis, aging diabetes, cancer and gastrointestinal disorders. Results from biological and phytochemical studies indicate that medicinal plants have profound antioxidant potential that can be exploited further in the prevention and treatment of these devastating disorders (Mazumdar et al., 2008).

Hepatoprotective activity of this plant was also reported. The Ayurvedic preparations contain 75 to $80 \%$ of natural products (Aiyer and Komalammal, 1963). It is believed that Ayurvedic products have the capacity to purify the cells and tissues and also to prevent 
or remove the toxic products from the live cells. These are an important constituent in some ayurvedic preparations (Ani et al., 2011).

Strychnos potatorum (Linn.) belongs to the family Loganiaceae. Vernacular names of the plant are 'Thettambaral', 'Kathka', 'Nirmala', 'Kath', 'Chethaneeya', 'Chakshushya'. This plant is a medium sized deciduous tree having height upto 12 meters. Seeds and roots are used in medicinal preparations. It is popularly used to purify water in India. Seeds of this plant cure head diseases and urinary discharges. The roots are useful to treat Leucoderma and fruits for curing eye diseases, poisoning etc.

A study was carried out to evaluate the antioxidant potential and elucidate the active principles in it.

\section{Materials and Methods}

\section{Extract preparation}

Different plant materials were collected from local areas and other parts of the State. Plant materials were washed, rinsed with distilled water and dried in air. About 10 to 20 grams of the dried materials were taken and powdered using a warring blender. This powder was then taken for extraction with different solvents (Harborne, 1989, Cseke, 2004, Omer Ertuk 2006., Green, 2004., Nostro et al., 2000).

As solvents, methanol, ethanol, sterile water, hexane, chloroform, ethyl acetate, benzene, diethyl ether and acetone were used initially, on trial and error basis, and according to the yield, solvents were selected for final use of extraction. All these solvents were purchased from M/s Merck, Mumbai. Plant extracts were prepared using different extraction methods depending on the nature of the plant material and yield, as mentioned in the table 4.1. In general, the following methods were used for the extraction.

Cold method (Harbone method, 1989) (Thara et al., 2016)

This method was used with slight modification. In this method, 10 gm powder of the dried plant material (weight varies depending on the plant material) was taken and mixed with $100 \mathrm{ml}$ of AR grade methanol. It was mixed well and kept on an orbitory shaker at $200 \mathrm{rpm}$ for 15 to $20 \mathrm{hrs}$ in room temperature. The extract was then filtered using Whatman no. 1 filter paper. The procedure was repeated for three times or until clear supernatant solvent was formed. The supernatant was collected and evaporated to dryness. The residue thus obtained was weighed and used for further analysis. The percentage yield is calculated (Handa et al., 2006) .This method was employed for different plant materials using different solvents. Solvent having maximum yield was selected.

Test for phenolic compounds (Harborne, 1989, Mc Donald et al., 2001)

The presence of phenolic compounds was tested using Folin's - Ciocalteu (FC) reagent. In this method $1 \mathrm{ml}$ of the extract $(1 \mathrm{mg} / \mathrm{ml})$ was taken in a clean dry test tube and $5 \mathrm{ml}$ of FC reagent was added to it. $4 \mathrm{ml}$ of $1.5 \%$ sodium carbonate was added and then kept for 30', at room temperature for incubation. Development of blue colour confirmed the presence of phenolic compounds. The intensity of blue colour was estimated using a colorimeter and the same was graded as + for low, ++ for medium and +++ for high intensities. The gradation of intensity represents the quantity of the phenolic compounds present in it. 
Tests for determining the presence of flavonoids

\section{Ferric chloride method (Harborne, 1989.Parekh et al., 2006)}

The presence of flavanoid compounds in the extract was determined by ferric chloride method. In this method, $1 \mathrm{ml}$ of the extract was taken in a test tube and a few drops of ferric chloride $(0.1 \%$ in distilled water) were added to the test tube. It was mixed well and kept at room temperature for few minutes. The presence of flavanoid compounds was indicated by the development of green colour. The intensity of the colour was noted using a colorimeter.

\section{Alkaline test for flavanoids (Harborne, 1989)}

This test was used to identify the presence of flavanoids. In this method, $1 \mathrm{ml}$ of the extract was taken in a clean dry test tube and $0.2 \mathrm{ml}$ of $0.1 \mathrm{~N} \mathrm{NaOH}$ was added to it. Increase in intensity of the yellow colour was an indication of the presence of flavanoids. Few drops of dil. $\mathrm{HCl}$ were then added. The solution became colorless, showing the presence of flavanoids.

\section{Test for alkaloids (Chopra et al., 2005)}

The presence of alkaloids was determined using the following method. $5 \mathrm{ml}$ of the extract $(0.2 \%)$ was taken in a test tube and 1 $\mathrm{ml}$ of $2 \mathrm{mM} \mathrm{HCl}$ and $1 \mathrm{ml}$ of the Nessler's reagent were added to the tube and mixed well. Presence of orange precipitate was an indication of the presence of alkaloids.

\section{Test for terpenoids (Obeyedi et al., 1990)}

$1.0 \mathrm{ml}$ of the extract $(0.2 \%)$ was taken in a clean dry test tube and a few drops of concentrated $\mathrm{H}_{2} \mathrm{SO}_{4}$ were added to the test tube. It was kept in room temperature for 30 min. Lower layer of the above mixture was turned yellow to indicate the presence of terpenoids.

\section{Test for saponins (Vogel, 1958)}

$5 \mathrm{ml}$ of the extract was taken in a clean dry test tube and a few drops of $\mathrm{Na}_{2} \mathrm{CO}_{3}$ were added to it and mixed well. Presence of saponins was indicated by the formation of froth.

\section{Test for glycosides (Parekh et al., 2007)}

$2 \mathrm{ml}$ of the extract was taken in clean dry test tube and a few drops of $0.1 \%$ of $\mathrm{FeCl}_{3}$ and con. $\mathrm{H}_{2} \mathrm{SO}_{4}$ were added to it. It was then kept for few minutes. Formation of reddish lower layer and bluish green upper layer was an indication of the presence of glycosides.

The quantity of the compounds present in the mixture were graded and recorded as + for low level, ++ medium level, +++ high level and - for complete absence.

\section{Biochemical estimation of total phenolic and flavanoid compounds}

Biochemical estimations were done to determine the quantity of various secondary metabolites present in each extract.

\section{Estimation of total phenolic content}

Total phenolic content of the extracts were estimated using Folin-Ciocalteu method (Singelton et al., 1999).

\section{Chemicals used}

Folin-Ciocalteu (FC) reagent, Sodium carbonate (Merck), Gallic acid (SRL).

Stock solutions: Gallic acid stock $1 \mathrm{mg} / \mathrm{ml}$ in 
methanol, FC reagent 1:2 dilution and Sodium carbonate solution $1.5 \%$ in water.

$1 \mathrm{ml}$ of the extract $(1 \mathrm{mg} / \mathrm{ml})$ in methanol was taken in a clean dry test tube. $0.0 \mathrm{ml}, 0.1 \mathrm{ml}$, $0.2 \mathrm{ml}, 0.4 \mathrm{ml}, 0.6 \mathrm{ml}, 0.8 \mathrm{ml}$ and $1.0 \mathrm{ml}$ of the gallic acid (standered $1 \mathrm{mg} / \mathrm{ml}$ ) were taken in separate test tubes and made up to $1 \mathrm{ml}$ with distilled water. $5 \mathrm{ml}$ of $\mathrm{FC}$ reagent (1:2 diluted with distilled water) and $4 \mathrm{ml}$ of Sodium carbonate solution $(1.5 \%$ in distilled water) were added to each test tube including the extract in methanol. Test tubes were then kept for incubation for 30' at room temperature. Optical density (OD) was measured at 760nm using a UV-VIS spectrophotometer (UV-VIS 1604 Shimadzu).

A graph was plotted with concentration of gallic acid on $\mathrm{X}$-axis and OD on Y-axis. The amount of total phenolic compound present in the extract was determined from the graph and expressed as gallic acid equivalents.

$\mathrm{C}=\mathrm{c} \times \mathrm{V} / \mathrm{m}$ where

$\mathrm{C}=$ Total phenolic $(\mathrm{mg} / \mathrm{ml})$

$\mathrm{c}=$ concentration of gallic acid $(\mathrm{mg} / \mathrm{ml})$

$\mathrm{V}=$ volume of the extract in $\mathrm{ml}$

$\mathrm{m}=$ weight of the extract

This estimation was done in triplicate for each extract using gallic acid as standard. (Singelton et al., 1992, Glucin et al., 2002, Milisukas et al., 2004, Irfan et al., 2008 and Zexai et al., 2008). Average \pm SD value was calculated.

\section{Estimation of total flavanoids}

The total flavanoid content was estimated by the method described by Singelton et al., 1992, and Kessler, 2003,

Stock solutions required: Quercetin standerd$0.1 \mathrm{mg} / \mathrm{ml}$ in methanol, $1.5 \% \mathrm{NaOH}$ in water, $0.15 \%$ of $\mathrm{NaNO}_{2}$
$0.0 \mathrm{ml}, 0.2 \mathrm{ml}, 0.4 \mathrm{ml}, 0.6 \mathrm{ml}, 0.8 \mathrm{ml}, 1.0 \mathrm{ml}$ of the quercetin standard and $0.5 \mathrm{ml}$ of the extract were taken in 7 separate clean dry test tubes. Total volume in each test tube was made up to $2.0 \mathrm{ml}$ with distilled water and 2.0 ml of $0.15 \% \mathrm{NaNO}_{2}$ was added in each test tube. Test tubes were kept in room temperature for $5 \mathrm{~min}$. Then $2 \mathrm{ml}$ of $5 \% \mathrm{NaOH}$ was added to each test tube, mixed well and kept for 15 ' at room temperature. OD of each sample was taken at $510 \mathrm{~nm}$ using distilled water as blank. The experiment was carried out in triplicate. Mean \pm SD value was calculated. This procedure was repeated for each and every extract.

A graph was plotted with concentration of the quercetin standard on $\mathrm{X}$-axis and $\mathrm{OD}$ on $\mathrm{Y}$ axis. The concentration of the total flavanoids present in each extract was thus determined using the graph and expressed as quercetin equivalents.

Reverse Phase High pressure liquid chromatography: RP-HPLC (Thara et al., 2012)

Plant extracts which showed significant antimicrobial, antioxidant activities were analysed using HPLC. RP-HPLC-profiling was done using general method, changing the solvent system according to the plant material

\section{HPLC system}

HPLC unit with dual pump, rheo dyne injector, SPD photodiode array detector in combination with 6.12 SP5 integration software was used. The following chromatographic conditions were given for the present experiment.

Column: Lichrosper RP 18 e $5 \mu \mathrm{m}$ (Merck).

Detector: SPD PDA, Flow rate: 1ml/min, Injection volume: $20 \mu 1$. 
The mobile system and wavelength were selected according to the sample. The mobile phase used for different samples were as follows:

1. Strychnos potatorum:- Acetonitrile: methanol (50:50)

The finger prints were recorded in different wavelength and shown as overlaid chromatogram. A PDA detector was used for recording. The number of peaks and area of the peaks were noted.

\section{Determination of cytotoxicity (Moseman et al., 1983)}

Cytotoxicity test using Mice Spleen cells was done by Tryphan blue exclusion method.

\section{Principle}

The dead and damaged cells stain blue inside on treating with trypan blue and can be distinguished from viable cells. This is due to the toxic effect of the drug which makes pores on the membrane and trypan blue can enter inside the cells (Mossman et al., 1983).

\section{Materials required}

PBS (Phosphate buffered saline): NaCl-4.0 gm, KCl- 0.1gm, $\mathrm{Na}_{2} \mathrm{HPO}_{4}-0.72 \mathrm{gm}$, $\mathrm{KH}_{2} \mathrm{PO}_{4^{-}} 0.1 \mathrm{~g}$ dissolved in $500 \mathrm{ml}$ of double distilled water, gentamicin-50 $\mu \mathrm{g} / \mathrm{ml}$, trypan blue-1.0\% and sterile distilled water. Chemicals used were purchased from $\mathrm{M} / \mathrm{s}$. SRL, Mumbai.

\section{Preparation of cell lines}

Mice spleen cells were collected and cultured in RPM1 1640 (Roswell Park Memorial Institute) medium. Mice were dissected and spllen was collected and crushed in RPM1 medium. It was then centrifuged at $1000 \mathrm{rpm}$.
Pellet was collected, washed and diluted with phosphate buffer to get concentration of $10^{6}$ cells $/ \mathrm{ml}$. It was then incubated in RPM1 medium at $36^{\circ} \mathrm{C}$ for $18 \mathrm{hrs}$ in $\mathrm{CO}_{2}$ incubator. Cytotoxicity of plant extracts under study was tested using these mice spleen cells cultured in RPM1 1640 (Roswell Park Memorial Institute medium). The number of cells at $10^{-3}$ dilution was counted using a haemocytometer. Different dilutions $\left(10^{-1}\right.$, $\left.10^{-2}, 10^{-3}\right)$ of the extract were made in sterile water $(10 \mathrm{mg} / \mathrm{ml})$. Incubated the different concentration of the extract like $0.0 \mu \mathrm{g}, 5.0$, $10.0,50.0,100,200,500$ and $1000 \mu \mathrm{g} / \mathrm{ml}$ with the cell lines at concentration of $10^{6} \mathrm{cells} / \mathrm{ml}$ per well. The final volume was made up to $1.0 \mathrm{ml}$ with PBS and was incubated at $37^{\circ} \mathrm{c}$ for $4 \mathrm{hrs} .1 \mathrm{ml}$ of $1 \%$ trypan blue (in distilled water) was added to each tube and mixed well. One drop was placed on each side of the haemocytometer and the number of dead cells were counted (10x) (Table.4.5).

$\%$ toxicity $=($ Number of dead cells $/$ Total number of cells) x 100

The experiment was repeated for 12 extracts and $\%$ cytotoxicity was determined for each extract. Data obtained were plotted on a graph with concentration of extract on $\mathrm{X}$-axis and \% toxicity on $\mathrm{Y}$-axis for calculating $\mathrm{IC}_{50}$ values of each extract (Fig 24).

\section{Determination of antioxidant activity}

\section{Diphenyl di picryl phenyl hydrazyl (DPPH) method}

This method was used to determine the antioxidant activity of different extracts (Kolleva, 2002).

\section{Principle}

Antioxidants can scavenge the DPPH and reduce to hydrazine. The colour or absorbance 
of the DPPH will be reduced on reduction by an antioxidant compound. So a decrease in absorbance of the reaction mixture is the indication of the antioxidant activity of the compound added. The difference in absorbance can be calculated by measuring the OD using a spectrophotometer.

\section{Materials required}

DPPH (SRL) - 0.1mM in methanol, extract at concentrations of $10,25,50,100$, and $200 \mu \mathrm{g} /$ $\mathrm{ml}$ in methanol, ascorbic acid standard $(100 \mu \mathrm{g} / \mathrm{ml})$ and distilled water. Chemicals used were of AR grade.

\section{Procedure}

$500 \mu \mathrm{l}$ of the sample was taken in a test tube. DPPH was prepared in methanol at a concentration of $0.1 \mathrm{Mm} .1 \mathrm{ml}$ of the DPPH was then added to the extract and mixed well. It was kept at room temperature for $20 \mathrm{~min}$., OD was measured at $517 \mathrm{~nm}$ using a UV-VIS spectrophotometer.

Ascorbic acid was taken as control. Negative control was DPPH without the extract. Percentage activity was calculated using the formula given below,

$\%$ activity $=1-\left(\left[\mathrm{A}_{\text {sample/ }} \mathrm{A}_{\text {control }}\right] \times 100\right)$.

The experiment was done in triplicate for each extract. Mean value \pm SD was calculated. $\mathrm{IC}_{50}$ (Inhibitory concentration for $50 \%$ activity) value for each extract was determined utilizing linear regression formula by plotting graph with concentration on $\mathrm{X}$ axis and percentage of inhibition on Y-axis.

Table.1 Percentage yield for each plant extract

\begin{tabular}{|l|l|l|l|l|l|l|}
\hline $\begin{array}{l}\text { Name of the } \\
\text { plant }\end{array}$ & $\begin{array}{l}\text { Plant part used for Solvent used } \\
\text { the extraction } \\
*\end{array}$ & $\begin{array}{l}\text { Dry mass } \\
(\mathbf{g m})\end{array}$ & $\begin{array}{l}\text { \%yield } \\
* *\end{array}$ & $\begin{array}{l}\text { Extraction } \\
\text { method used } \\
* * *\end{array}$ & Designated as \\
\hline $\begin{array}{l}\text { Strychnos } \\
\text { potatorum }\end{array}$ & $\mathrm{S}$ & $\begin{array}{l}\text { Methanol } \\
\text { Ethanol } \\
\text { Water } \\
\text { Chloroform }\end{array}$ & $\begin{array}{l}\text { 0.12 } \\
\text { ND } \\
\text { ND } \\
\text { ND }\end{array}$ & $\begin{array}{l}\text { ND.5 } \\
\text { ND } \\
\text { ND }\end{array}$ & C & CP1 \\
\hline
\end{tabular}

Various metabolites present in the extracts

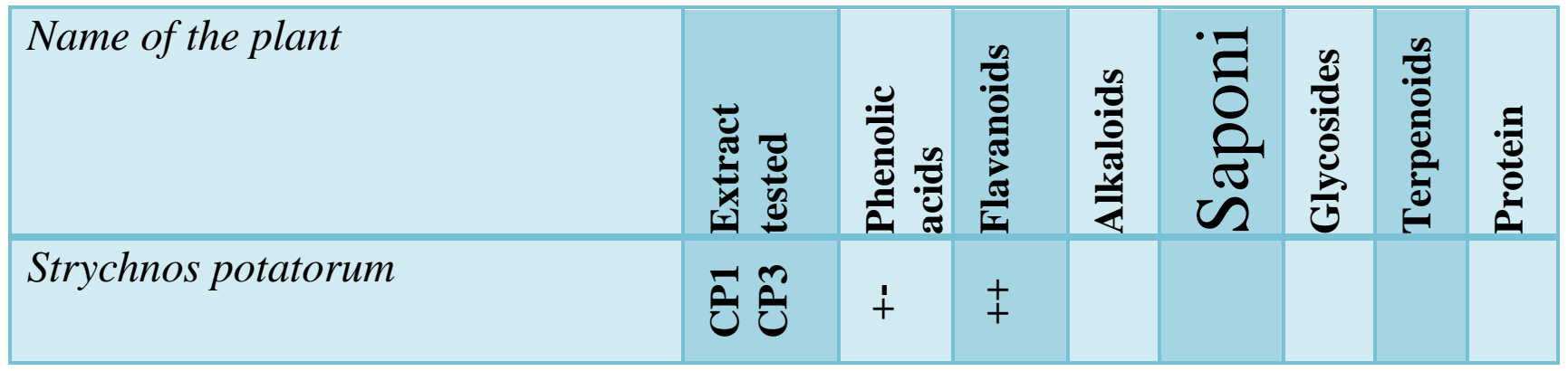


Table.3 Total phenolics and flavanoids in the extracts

\begin{tabular}{|l|lr|l|l|}
\hline Name of the plant & $\begin{array}{l}\text { Extract } \\
\text { for } \\
\text { estimation }\end{array}$ & $\begin{array}{r}\text { used } \\
\text { the }\end{array}$ & $\begin{array}{l}\text { Total phenolics } \\
\text { as Gallic acid } \\
\text { equivalents }\end{array}$ & $\begin{array}{l}\text { Total flavanoids as } \\
\text { Quercetin } \\
\text { equivalents }\end{array}$ \\
\hline Strychnos potatorum & CP1 & $\mathbf{2 5 . 1 + 3 . 2}$ & ND \\
\hline
\end{tabular}

Figure.1 HPLC profiling of methanol extracts of seeds of Strchnos potatorum

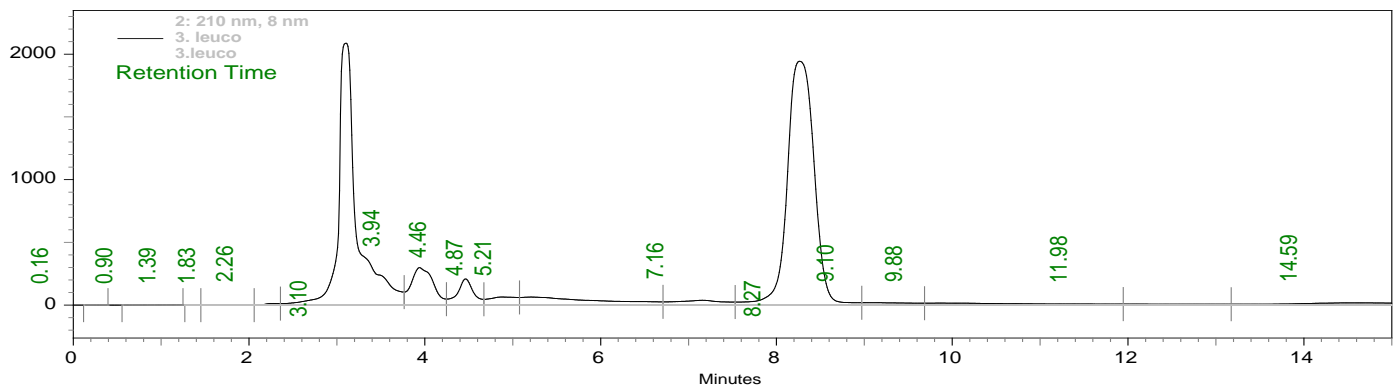

Quantification of Quercetin and Kaempferol in Strychnos potatorum
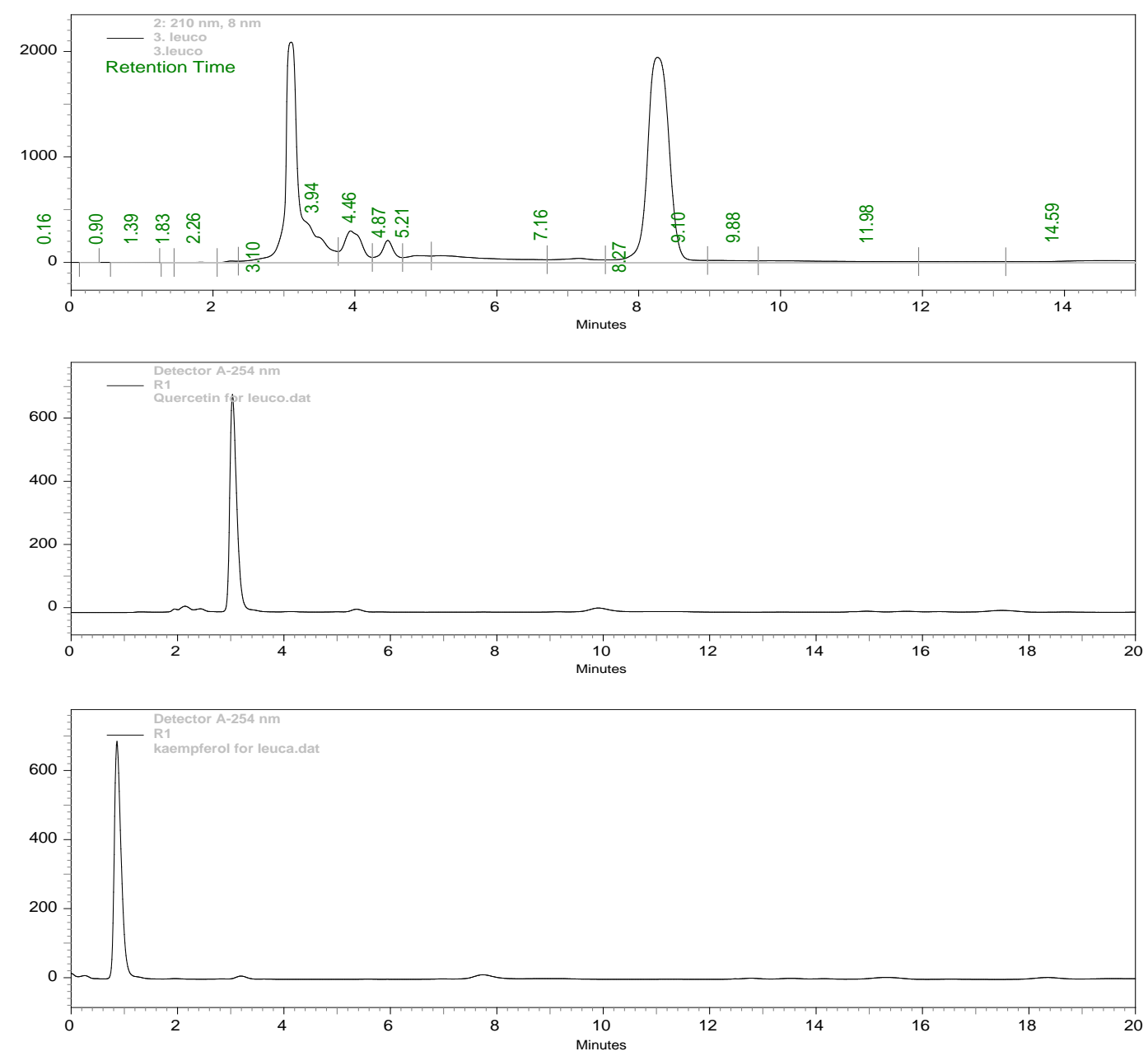


\section{Quantification of Quercetin and Kaempferol in Strychnos potatorum}

Concentration of Sample: $\mathbf{2 0} \mathbf{m g} / \mathbf{m l}$ (wrt dry extract weight)

Concentration of Std Quercetin: 100ug/ml (1 mg dissolved in 10ml)

Concentration of Std Kaempferol: 100ug/ml (1 mg dissolved in 10ml)

Retention time of Quercetin: 3.08

Retention Time of Kaempferol: 0.78

Percentage purity of injected Quercetin: $98 \%$

Percentage purity of injected Kaempferol: 99\%

Area given by Standard Quercetin in the standard profile: $\mathbf{6 8 9 5 4 7 5 8}$

Area given by Standard Kaempferol in Standard profile: $\mathbf{5 6 8 5 9 2 6 3 4}$

Area given by Quercetin in sample profile: $\mathbf{1 2 2 4 2 5 7 3}$

Area given by Kaempferol in sample profile: $\mathbf{9 0 9 3}$

\section{Result}

\section{The percentage of Quercetin in the sample: $0.85 \%($ w/w $)$}

The percentage of Kaempferol in the sample: $0.0065 \%(w / w)$

$0.85 \%$ of quercetin was present in the extract of Strychnos potatorum, while it contained kaempherol in comparatively very low level $(0.0065 \%)$. The medicinal properties of the above three extracts can be due to the presence of these flavanoid compounds- quercetin, kaempherol or both.

Table.6 Antioxidant activity of extracts

\begin{tabular}{|l|l|l|}
\hline Name of the plant & Extract used & $\begin{array}{l}\text { IC }_{50} \text { VALUE } \\
\text { DPPH ACTIVITY } \\
\mu \mathrm{g} / \mathrm{ml}\end{array}$ \\
\hline $\begin{array}{l}\text { Strychnos } \\
\text { potatorum seed }\end{array}$ & Water & $\mathbf{7 0}$ \\
\hline & Methanol & $\mathbf{5 0 . 5}$ \\
\hline & Chloroform & 95.5 \\
\hline
\end{tabular}

Table.7 Cytotoxicity assay for various extracts

\begin{tabular}{|l|l|l|l|}
\hline Name of the plant & $\begin{array}{l}\text { Extract used for } \\
\text { the estimation }\end{array}$ & $\begin{array}{l}\text { Normal } \\
\text { Mice spleen cells } \\
\text { \% inhibition }\end{array}$ & $\begin{array}{l}\text { IC } \\
\text { for 50\% inhibition) }\end{array}$ \\
\hline 7) Strychnos potatorum & CP1 & $\mathbf{1 0}$ & $\mathbf{1 0 7 9 . 8 5}$ \\
\hline & Methanol & $\mathbf{1 2}$ & $\mathbf{1 2 6 0 . 5}$ \\
\hline & Chloroform & $\mathbf{5}$ & $\mathbf{1 3 0 0 . 0}$ \\
\hline
\end{tabular}


Strychnos potatorum: This has been traditionally used against diarrhea, eye diseases, diabetes and bronchitis (Shanmugapriya, 2008). But as per this study, this plant extract has not been a successful antimicrobial agent. The MIC value obtained was above $5000 \mu \mathrm{g} / \mathrm{ml}$ for all the pathogens under study. The aqueous extract of $S$. potatorum has shown the presence of alkaloids, glycosides and proteins, though no flavanoid was present. HPLC choromatogram at $210 \mathrm{~nm}$ showed the presence of two major and two minor peaks. There was $90 \%$ viability shown on EAC cell lines, in the MTT assay, indicating that the extract is less toxic or inhibitory on cancer cells, thus being a weak antiproliferating agent.

In conclusion, Strychnos potatorum is can be used in alternative medicine for relieve life style diseses,in functional food etc. It has good antioxidant effect with good flavaniod content.

\section{Acknowledgment}

I acknowledge University of Calicut for providing me the infra structure facilities.

\section{References}

Aiyer, K. N. and Kolammal, M., 1963. Pharmacognosy of Ayurvedic Drugs, Dept of Pharcognosy, Uty. Of Kerala, Trivandrum.

Almeida, I., Fernandes, E., Lima, J., Costa, P., Bahia, M.F., 2008. Walnut (Juglans regia) leaf extracts are strong scavengers of pro-oxidant reactive species. Food Chemistry 106, 10141020.

Ani, V and Naidu, K.A. 2011. Antioxidant potential of bitter cumin (Centratherum anthelminticum (L.) Kuntze) seeds in in vitro models. BMC Complementary and Alternative Medicine.
Cseke, L.J., Kirakosyan, A., Kaufman, P.B., Warber, S.L., Duke, J.A., Brelmann, H.L. 2009. Phytochemicals, Chemical components from plants. Natural products from plants. $2^{\text {nd }}$ ed., pp3-40. CRC press, Taylor and Francis group, Suite 300, Boca Raton, FL 33487-2742.

Handa, S.S. 2006. An overview of extraction techniques for medicinal and aromatic plants. South East Asia Regional Workshop on Extraction Technologies for Medicinal and Aromatic plants.

Harborne, J.B., 1992. Heftmann E (5th eds) Chromatography: Elsevier, Amsterdam, pp. B363-92.

Kavita N. Yadav, Prasad V. Kadam, Jigna A. Patel, and Manohar J. Patil, 2014, Strychnos potatorum: Phytochemical and pharmacological review, Pharmacogn Rev. 2014 Jan-Jun; 8(15): 61-66.

Kessler, M., Ubendu, G.C., Jung, L., 2003. Antoprooxidant activity of rutin and quercetin derivatives. J. Pharm. Pharmacol. 55(2), 131-142.

Koleva, I., Teris A. van Beek, Jozef P. H. Linssen, Aede de Groot, Lyuba N. Evstatieva., 2001. Screening of Plant Extracts for Antioxidant Activity: a Comparative Study on Three Testing Methods. Phytochemical Analysis, 13(1), 1-17.

McDonald ,S., Prenzler, P.D., Autolovich ,M., Robards, K. 2001. Phenolic content and antioxidant activity of olive extracts. Food Chemistry, 73, 73-84

Mosmann, T., 1983. Rapid colorimetric assay for cellular growth and survival: application to proliferation and cytotoxicity assays. Journal of Immunology Methods 65, 55-63.

Odebiyi, O. O., and E. A. Sofowora. 1979. Antimicrobial alkaloids from a Nigerian chewing stick (Fagara zanthoxyloides). Planta Medica 36, 204-207.

Parekh, J., Karathia, N., Chanda, S.,2006. 
Screening of some traditionally used medicinal plants for potential antibacterial activity. Indian Journal of Pharmaceutical Science 68(6), 832-834. Singleton, V, L, Orthofer, R., and LamuelaRaventos, R.M., 1999.Analysis of total phenols and other oxidation substrates and antioxidants by means of Folin-
Ciocalteu reagent. Methods Enzymol 299, 152-178.

Thara K. M., Zuhara K. F., 2012, Biochemical HPLC, LCMS analysis and biological activities of methanol extract of Alstonia scholaris, 3,International journal of phyotherapy, 61-74.

\section{How to cite this article:}

Thara, K.M. 2020. Biochemical Profiling and Evaluation of Antioxidant and Cytotoxic Effect of Different Extracts of Strychnos potatorum. Int.J.Curr.Microbiol.App.Sci. 9(02): 1308-1317. doi: https://doi.org/10.20546/ijcmas.2020.902.154 